\title{
Analysis of Cost and Return Structure of Chickpea Cultivation
}

\author{
R.V. Chavan*, R.D. Shelke and S.S. More \\ Department of Agricultural Economics, Vasantrao Naik Marathwada Krishi Vidyapeeth, \\ Parbhani, India \\ *Corresponding author
}

\section{A B S T R A C T}

\section{Keywords}

Cost and return structure, Chickpea, Cost of production, Pulses

Article Info

Accepted:

26 April 2020

Available Online:

10 May 2020
Pulses are the edible seeds of plants in the legume family. Pulses grow in pods and come in a variety of shapes, sizes and colours. India grows chickpea on about 8.35 million hectares area with 7.17 million tons of grains which represents more than 40 per cent of the national pulse acreage and production respectively. Use of hired human labour and the family human labour was 33.73-man days and 12.46-man days respectively. Use of bullock labour was 4.86 pair days while the use of machine labour was 18.00 hours. The main produce (grain) was produced was 15.56 quintals and by produce (straw) was 4.04 quintals. The farm business income comes to Rs.41237.53 likewise family labour income was Rs.28583.58. Per quintal cost of production of chickpea was Rs.3075.25 and Output-Input ratio was 1.53 .

\section{Introduction}

Pulses are the edible seeds of plants in the legume family. Pulses grow in pods and come in a variety of shapes, sizes and colours. The pulses are also a rich source of green and dry fodder for livestock production. Therefore, pulses are important in cropping pattern. The major pulses chickpea, pigeon pea, lentil, green gram and black gram account for nearly 80 per cent of total pulse production in India. India's total pulse production in turn accounts for 29 per cent of World area and 19 per cent of World production. As a share of total food expenditure, pulses represent about 5 per cent. Among pulses, pigeon pea is the most heavily consumed pulse contributing more than 30 per cent of total pulse expenditure though the type of pulses demanded varies significantly across the states.

The chickpea (Cicer arietinum) belongs to Fabaceae family. It was a small, branched herbaceous plant. Chickpea is the second most important grain legume in the world after dry bean. The world's total production of chickpeas covers around 8.5 million metric tons annually and is grown over 10 million 
hectares of land approximately. India grows chickpea on about 8.35 million hectares area with 7.17 million tons of grains which represents more than 40 per cent of the national pulse acreage and production respectively. States like Madhya Pradesh, Karnataka, Rajasthan, Maharashtra, Andhra Pradesh and Chhattisgarh together contribute more than 90 per cent of production from more than 90 per cent area. Since 1990, a rise in productivity of chickpea in India has been observed from $614 \mathrm{~kg} / \mathrm{ha}$ to $859 \mathrm{~kg} / \mathrm{ha}$.

Keeping in view the above aspects, the present study has been undertaken with following objective includes, to study the input use, cost structure and profitability of chickpea

\section{Materials and Methods}

This chapter deals with the blueprint of research and the sources of data. It was intended to describe methodology clearly adopted to accomplish the objectives of study.

Multi stage sampling design was adopted for selection of districts, tehsils, villages and chickpea growers. In the first stage, three districts namely Parbhani, Hingoli and Latur were purposely selected from Marathwada region.

In the second stage, from each district two tahsils were selected on the basis of more area under chickpea cultivation.

In third stage, list of predominant villages with respect to area under chickpea were obtained from selected tehsils. From each tehsil, two villages were selected purposely. In the fourth stage, from the list of chickpea growers, ten chickpea growers were randomly selected from each village. In this way, from three districts, one hundred twenty chickpea growers were selected for the present study.
The data was collected from cultivars with the help of pre-tested schedule through personal interview method. The data pertains for the year 2018-19.

Regarding marketing of chickpea, three district level markets viz, Parbhani, Hingoli and Latur were selected for present study.

\section{Results and Discussion}

\section{Costs, returns and profitability of chickpea growers}

To study the cost, returns and profitability in chickpea production the physical inputs required were taken and converted into monetary term to determine the cost of cultivation per hectare. Similarly, main produce and by produce were converted into monetary terms to know the gross returns. Thus with the help of costs and returns, profitability of chickpea production was determined as follows.

\section{Per hectare physical inputs and output of chickpea}

Per hectare physical inputs and output of chickpea were calculated and presented in Table 1. Results revealed that use of hired human labour and the family human labour was 33.73 man days and 12.46 man days respectively. Use of bullock labour was 4.86 pair days while the use of machine labour was 18.00 hours. In case of fertilizers, use of Phosphorus was $46.56 \mathrm{~kg}$ followed by 21.87 $\mathrm{kg}$ of Nitrogen and very negligible amount of potash was used i.e. $1.77 \mathrm{~kg}$ per hectare, while 1.86 litres of plant protection was used to control pest and diseases on chickpea. The main produce (grain) was produced was15.56 quintals and by produce (straw) was 4.04 quintals. 
Table.1 Per hectare physical inputs and output of chickpea growers

\begin{tabular}{|c|l|c|c|}
\hline Sr.No. & Particulars & Physical unit & chick pea farm \\
\hline & INPUT & & \\
\hline $\mathbf{1 .}$ & Hired human labour & manday & 33.73 \\
\hline $\mathbf{2 .}$ & Bullock labour & pairday & 4.86 \\
\hline $\mathbf{3 .}$ & Machine labour & hour & 18.00 \\
\hline $\mathbf{4 .}$ & Seed & $\mathrm{kg}$ & 69.55 \\
\hline $\mathbf{5 .}$ & Fertilizer & $\mathrm{kg}$ & \\
\hline & $\mathrm{N}$ & $\mathrm{kg}$ & 21.87 \\
\hline & $\mathrm{P}$ & $\mathrm{kg}$ & 46.56 \\
\hline & $\mathrm{K}$ & $\mathrm{liter}$ & 1.77 \\
\hline $\mathbf{6 .}$ & Plant protection & manday & 1.86 \\
\hline $\mathbf{7 .}$ & Family human labour & & 12.46 \\
\hline & & & \\
\hline & OUTPUT & $\mathrm{q}$ & 15.56 \\
\hline $\mathbf{8 .}$ & Main produce (grain) & $\mathrm{q}$ & 4.04 \\
\hline $\mathbf{9 .}$ & By-produce (straw) & & \\
\hline & & & \\
\hline
\end{tabular}

Table.2 Per hectare cost and returns of chickpea growers

\begin{tabular}{|c|c|c|c|}
\hline \multirow{2}{*}{$\begin{array}{l}\text { Sr. } \\
\text { No. }\end{array}$} & \multirow[t]{2}{*}{ Particulars } & \multicolumn{2}{|c|}{ Chick pea farm } \\
\hline & & $\begin{array}{l}\text { Amount } \\
\text { (Rs. /ha) }\end{array}$ & Per cent \\
\hline 1. & Hired human labour & 7589.58 & 15.68 \\
\hline 2. & Bullock labour & 2430.56 & 5.02 \\
\hline 3. & Machine labour & 9345.06 & 19.30 \\
\hline 4. & Seed & 6447.64 & 13.32 \\
\hline \multirow[t]{3}{*}{5.} & Fertilizers $\mathrm{N}$ & 285.19 & 0.59 \\
\hline & $\mathrm{P}$ & 1818.46 & 3.76 \\
\hline & K & 48.93 & 0.10 \\
\hline 6. & Plant protection & 1408.57 & 2.91 \\
\hline 7. & Land revenue & 95.61 & 0.20 \\
\hline 8. & Incidental charges & 905.59 & 1.87 \\
\hline 9. & Interest on working capital & 987.19 & 2.04 \\
\hline 10. & Depreciation on capital assets & 1595.37 & 3.30 \\
\hline 11. & Cost-A $(\Sigma 1-11)$ & 32957.76 & 68.07 \\
\hline 12. & Rental value of land & 12270.27 & 25.34 \\
\hline 13. & Interest on fixed capital & 383.68 & 0.79 \\
\hline 14. & Cost-B $(\Sigma 12-14)$ & 45611.71 & 94.21 \\
\hline 15. & Family human labour & 2804.17 & 5.79 \\
\hline 16. & Cost-C ( $(\Sigma 15-16)$ & 48415.88 & 100.00 \\
\hline
\end{tabular}


Table.3 Per hectare profitability in chickpea production

\begin{tabular}{|c|l|c|c|c|}
\hline Sr. No. & \multicolumn{1}{|c|}{ Particulars } & Unit & Quantity & Amount (Rs) \\
\hline $\mathbf{1}$ & Return from main produce & q & 15.56 & 73616.67 \\
\hline $\mathbf{2}$ & Return from by-produce & $\mathrm{q}$ & 4.04 & 578.63 \\
\hline $\mathbf{3}$ & Gross return & & & 74195.30 \\
\hline $\mathbf{4}$ & Cost-A & & 32957.76 \\
\hline $\mathbf{5}$ & Cost-B & & 45611.71 \\
\hline $\mathbf{6}$ & Cost-C & & 48415.88 \\
\hline $\mathbf{7}$ & $\begin{array}{l}\text { Farm Business Income } \\
\text { (Gross returns minus Cost-A) }\end{array}$ & & 41237.53 \\
\hline $\mathbf{8}$ & $\begin{array}{l}\text { Family Labour Income } \\
\text { (Gross returns minus Cost-B) }\end{array}$ & & 28583.58 \\
\hline $\mathbf{9}$ & Net Profit & & 25779.41 \\
\hline $\mathbf{1 0}$ & $\begin{array}{l}\text { (Gross returns minus Cost-C) } \\
\text { Output-Input ratio } \\
\text { (Gross returns divided by Cost-C) }\end{array}$ & & \\
\hline $\mathbf{1 1}$ & $\begin{array}{l}\text { Per quintal cost of production } \\
\text { (Cost-C minus value of by-produce \& } \\
\text { dividing by quantity of main produce) }\end{array}$ & & & 1.53 \\
\hline & & & 3075.25 \\
\hline
\end{tabular}

Per hectare costs and returns of chickpea

Per hectare costs and returns of chickpea were calculated and presented in Table 2. It was observed from the table that Cost-C was Rs.48415.88 in which the share of Cost-B was 94.21 per cent followed by Cost-A was 68.07 per cent. Among all the items of variable expenditure the major portion is contributed by machine labour to the tune of 19.30 per cent, 15.68 per cent and 13.32 per cent respectively. In case of fixed expenses the rental value of land contributed major portion of the fixed cost i.e. 25.34 per cent. Other items such as phosphorus application, plant protection, incidental charges, interest on working capital and depreciation contributes 3.76 per cent, 2.96 percent, 1.87 per cent, 2.04 per cent and 3.30 per cent respectively.
Per hectare profitability in chickpea

Per hectare profitability in chickpea production was calculated and presented in Table 3. It was observed from the table the main produce produced was 15.56 quintals and by produce was 4.04 quintals. Per quintal average price of chickpea was Rs. 4731.14. Gross returns were Rs.74195.00 in which main produce was of Rs.73616.67 and by produce Rs.578.63. It was evident from the table that per hectare net profit from chickpea cultivation crop was gained Rs.25779.41. The farm business income was calculated by subtracting Cost-A from Gross returns which came to Rs.41237.53 likewise family labour income was Rs.28583.58. Per quintal cost of production of chickpea was Rs.3075.25 and Output-Input ratio was 1.53. 
In conclusions, use of hired human labour and the family human labour was 33.73-man days and 12.46-man days respectively. Use of bullock labour was 4.86 pair days while the use of machine labour was 18.00 hours. The main produce (grain) was produced was 15.56 quintals and by produce (straw) was 4.04 quintals. The farm business income comes to Rs.41237.53 likewise family labour income was Rs.28583.58. Per quintal cost of production of chickpea was Rs.3075.25 and Output-Input ratio was 1.53.

\section{Policy implications}

As chickpea is short durational crop and having better $\mathrm{B}: \mathrm{C}$ ratio farmers should increase the area under chickpea production.

Producers must have supported with better storage facilities to fetch better remunerative price to their produce.

\section{References}

Amutha, D. 2013. Analysis of cost and return structure of cowpea cultivation.
International Journal of Retailing \& Rural Business Perspectives, 2(3): 496498.

Asmatoddin, M., S.V. Jawale and D.S. Perke, 2009. Economic analysis of pulse production on medium farm in Marathwada. Agriculture Update, 4(3\&4): 262-265.

Banafar,K. N. S., 2012. Profitability in cultivation of pulses: an economist view in Chhattisgarh perspective. Model Training Course on Production Techniques in Rabi Pulses, 09-16 January, 2012. Directorate of Extension Services, Indira Gandhi Krishi Vishwavidyalaya, Raipur, Chhattisgarh.

Bansode, P.S., 2008. Economic analysis of marginal farm in Marathwada region of Maharashtra. M.Sc. (Agri) Thesis, submitted to Marathwada Agricultural University, Parbhani, 93p.

Bhagwat, M.Z., 2008. Economic analysis of small farm in Marathwada region of M.S. M.Sc. (Agri) Thesis, Submitted to Marathwada Agricultural University, Parbhani, 102p.

\section{How to cite this article:}

Chavan, R.V., R.D. Shelke and More, S.S. 2020. Analysis of Cost and Return Structure of Chickpea Cultivation. Int.J.Curr.Microbiol.App.Sci. 9(05): 3009-3013. doi: https://doi.org/10.20546/ijcmas.2020.905.357 